\title{
Social Perception of Wind Energy in the Isthmus of Tehuantepec
}

\author{
Eduardo Martínez Mendoza ${ }^{1}$, Luis Arturo Rivas Tovar ${ }^{2}$, Gregorio Fernández Lambert ${ }^{3}$, Paola Selene Vera \\ Martínez $z^{3} \&$ Franciso Ballina Ríos ${ }^{4}$ \\ ${ }^{1}$ Department of Industrial Engineering, Universidad del Istmo, Oaxaca, México \\ ${ }^{2}$ Administrative Sciences by the Instituto Politécnico Nacional, México \\ ${ }^{3}$ Department of Industrial Engineering, Instituto Tecnológico Superior de Misantla, Veracruz, México \\ ${ }^{4}$ School of Accounting and Management, Universidad Nacional Autónoma de México, México \\ Correspondence: Eduardo Martínez Mendoza, Department of Industrial Engineering, Universidad del Istmo, \\ Oaxaca, México. Tel: 1-971-702-0416. E-mail: ed_mtzm@hotmail.com
}

Received: July 18, 2015 Accepted: August 7, 2015 Online Published: November 29, 2015

doi:10.5539/jsd.v8n9p206 URL: http://dx.doi.org/10.5539/jsd.v8n9p206

\begin{abstract}
This article discusses the perception that landowners in Oaxaca, Mexico have about wind farms and their related environmental, social, and economic impact. Taking as ref-erence international studies, a wind farm developer, owners and academics, a question-naire was designed to gather information. We found that landowners have positive opinions to changing their agricultural activity and support wind energy because it appears to generate jobs and incomes. It is also considered a clean source of generating energy. Overall, respondents expressed attitudes supporting the installation of the wind farm.
\end{abstract}

Keywords: wind power, wind energy, community organization, social impacts, Oaxaca, Mexico

\section{Introduction}

Wind energy is pollution-free, which means that it does not generate greenhouse gases or toxic waste. It has an infinite supply source (Han, Mol, Lu, \& Zhang, 2009), compared with solar, geothermal and hydropower energy. Wind is the most sustainable source of electricity (Evans, Strezov, \& Evans, 2009). It is estimated that within three to six months of operation, the wind turbines have offset all emissions caused during their construction (Barbará-Gómez, 2009), however, the development of wind power is controversial (Rygg, 2012). Some people see wind farms as a destructive agent to the environment and landscapes because they require large amounts of land. Moreover, the turbines are visible from long distances (Rygg, 2012), and the noise and visual impact are issues that generate increasing local resistance to the development of wind farms (Dai, Bergot, Liang, Xian, \& Huang, 2015; Wolsink, 2013; Baxter, Morzaria, \& Hirsh, 2013; Barbará-Gómez, 2009).

In the last few decades, there have been many proposed or installed renewable energy projects worldwide. Some studies suggest that support is actually quite high in communities living with wind turbines (Baxter, Morzaria, \& Hirsh, 2013). In Greece, Kaldellis, Kapsali, \& Katsanou (2012) found that only $6 \%$ of their sample was against the presence of renewable energy projects. Also in Greece, Kaldellis (2005) found that acceptance levels were above $80 \%$ on the islands, while on the mainland levels were $40 \%$. Eventhough the study refers to the same region, the appraisals in the two sceneries are different. In the UK, two thirds of the population supports investment in renewable energy, particularly wind power (Devine-Wright, 2007).

However, sometimes local residents have opposed wind power generation (Kaldellis, Kapsali, \& Katsanou, 2012). The main concern is the deterioration of the landscape associated with the installation of turbines and transmission lines (Misrasgedis, Tourkolias, Tzovla, \& Diakoulaki, 2014; Jobert, Laborge, \& Mimler, 2007). Other concerns are noise pollution and bird deaths (Han, Mol, Lu, \& Zhang, 2009; Evans, Strezov, \& Evans, 2009). These concerns have led to research on the acceptance of wind energy, which has grown in recent years (Walter, 2014). In fact, from 1987 to 2012 only 147 articles related to the acceptance of renewable energy were identified (Fast, 2013). The research related with this topic consists mainly of empirical studies of public attitudes towards wind energy, mostly through questionnaires or surveys using a quantitative approach (Devine-Wright, 2007).

Visual impact is one of the most recurrent themes in research for determining acceptance factors of wind energy 
(Jobert, Laborge, \& Mimler, 2007). Visual impact is not only associated with turbines, but also with transmission lines (Soini, Pouta, Salmiovirta, Uu-sitalo, \& Kivinen, 2011). It is one of the most sensitive issues, and it depends, among other things, on the structure and accessibility of the landscape, socioeconomic conditions and traditions (Hammarlund \& Martensson, 1999) as well as attachment to the place, appropriation of space and social representations (Improta, 2011).

The landscape can be viewed in many different ways depending on the individual. It is the scenery of several daily activities, and perceptions are different if the person is a resident who lives on the land, or a person doing recreational activities, or a person who sees it from the window of a car (Soini, Pouta, Salmiovirta, Uusitalo, \& Kivinen, 2011), a tourist for instance, where satisfaction can be affected by modifying the attributes of the destination (León-González, Araña-Padilla, González-Hernández, \& Suárez-Reina, 2013; Rygg, 2012). The perception of visual impacts is subjective and influenced by psychological factors (Misrasgedis, Tourkolias, Tzovla, \& Diakoulaki, 2014).

The construction of roads, which implies changes in the flora, fauna, and natural channels of rainwater, constitutes another alteration due to wind energy projects. During the construction of a wind farm, some activities such as excavation for foundations and road construction may affect the biosystem (Dai, Bergot, Liang, Xian, \& Huang, 2015).

Regarding the noise generated by wind farms, there are also conflicting attitudes. According to van den Berg (2004), residents living within 500 meters of a wind farm with seventeen 98 meter high turbines have strongly reacted to the noise. Those living 1,900 meters away have also experienced discomfort. Pedersen \& Persson (2004) found that the noise of wind turbines annoyed more respondents than noise from other sources in the community.

Although noise and degradation to the landscape are recognized as major problems of acceptance for the development of wind farms, for Devine-Wright (2007), there are many factors that determine the successful implementation of renewable energy, which can be classified as personal, socio-psychological and contextual factors. Therefore, an interdisciplinary approach using qualitative and quantitative techniques is required to understand these factors. Indeed, it is necessary to reconsider the attention given to these challenges (Pasqualetti, 2011). Social barriers to renewable energy have been undervalued and underestimated. Neglecting this topic can inhibit, redirect, or even prevent wind projects.

Most countries have incorporated the dimension of social resistance ex-post facto, this is to say, after wind energy has been developed as part of the energy mix, and after experiencing problems and/or difficulties (Trobo, 2013). Some of the countries that have experienced conflict to the development of wind projects are Spain, Germany, France, the United States, and Mexico (Trobo, 2013; Pasqualetti, 2011; Devine-Wright, 2007; Jobert, Laborge, \& Mimler, 2007).

Despite the controversy during its development, the installed wind capacity has grown rapidly around the world, mainly because it is an environmentally friendly source energy with the environment. In 1999 in Spain, the Association of Renewable Energy Producers rated seven sources of power generation by means of ecopoints, which measure the environmental and social impact during the electricity production and the impact that occurrs throughout their life cycle. Some of the sources of electricity generation that were evaluated were oil, small-scale hydroelectric schemes, and wind farms. According to the study, each terajoule (Note 1) of electricity generated using oil is equivalent to 1398.11 ecopoints. Each terajoule of small hydroelectricity generate 5.43 ecopoints--this being the source that produced the smallest impact. Every terajoule generateded by wind farms produced 64.67 ecopoints, ranking as the second source of energy with the least environmental impact (Association of Renewable Energy Producers, 1999).

The low environmental impact, improved technology, better efficiency, reliability and lower costs have motivated the growth of wind energy (Huacuz, 2010). The installed (cumulative) capacity of wind energy generation grew around the world from 6,100 MW in 1996 to 318.13 MW in 2013. In December of that same year, China, the United States, Germany, Spain, and India accumulated 72.20 percent of the total cumulative installed capacity worldwide (Global Wind Energy Council, 2014). This was due to the incentives that those countries had granted for the development of renewable energy.

In Mexico, the first wind farm was inaugurated in 1994 in the village La Venta, in the Isthmus of Tehuantepec, in the state of Oaxaca. The wind farm La Venta was built as a prototype project. It was the first in this country and in Latin America (del Campo, Nelson \& García, 2009). However, in 2006 wind energy really began to develop in the country. The cumulative installed capacity of wind power has increased from $3 \mathrm{MW}$ in 2005 to $1,370 \mathrm{MW}$ in 2012 (Global Wind Energy Council, 2012). Wind farms were mostly installed in the Isthmus of Tehuantpec. 
Mexico has a great potential for wind power generation, over 71,000 MW (Alemán-Nava et al, 2014). During 2012, Mexico increased its capacity to $623 \mathrm{MW}$, reaching $1992 \mathrm{MW}$ in 2013 (Global Wind Energy Council, 2014). Fifteen out of the nineteen wind farm projects in Mexico are installed in the Isthmus of Tehuantepec, in the state of Oaxaca, where the estimated potencial is about 40,000 MW. The winds of the Isthmus of Tehuantepec are categorized as the best in the world to install wind farms. Its power factors are between 42 and 50 percent (SE, 2013).

In the Istmus of Tehuantepec, wind farms are distributed in Juchitán de Zaragoza, La Venta, La Ventosa, El Espinal, La Mata, Asunción Ixtaltepec, Santo Domingo Ingenio, and Unión Hidalgo. In accordance with García (2011), in 2011 there were 351 operating wind turbines in that zone, and in 2013475 wind turbines were installed (The Wind Power, 2014; Grupo Bimbo, 2013; Enel Green Power, 2012; Energy News, 2012). Such an amount is equivalent to 80 percent of the total wind turbines installed in Mexico. During the development of those wind farms some social conflicts arose and caused fights between the villagers and the police, legal trials, injuries, deaths and a project was cancelled (Déniz, de la Rosa \& Verona (2012), Bárcenas (2012), Beas (2012), Matías (2012) and, Thomas (2013).

The analysis of social attitudes towards wind energy is an important issue in the world. Many analyses have been done to understand how people feel where wind farms have been built. Carro (2008) indicates that many studies provide evidence of positive attitudes towards wind energy. He also affirms that there is evidence that the conflicts related to the development of new wind farms are more frequent and violent. The conflicts that have happened are due to the new use and distribution of land. Although the impact of renewable energy plants on the environment and landscape is less than the impact of conventional energy plants. Renewable energy (wind, solar, etc,) infrastructure causes new issues in territorial management policies and are related to the division and dispersion of land (Frolova 2010). This increases the number of decisions to make about their location and at the same time increases the possibility of conflicts related to the use of land. Castillo (2011) affirms that the growing use of wind energy technologies on a large scale in many countries such as Spain, Germany, Italy, among others has caused different negative socio-enviromental effects and the opposition of enviromental and human rights protection groups. .

This paper presents exploratory research that provides quantitative elements about the perception of landowners where a wind farm is installed in the Isthmus of Tehuantepec. Although there is qualitative research about this topic in the region, this paper is the first to use a quantitative approach. Some current analysis has been done by Déniz, de la Rosa \& Verona (2012) who evaluated the dissonance between the sustainability reports of the wind companies that operate in Oaxaca and the daily reality. Nahmad, in 2011, coordinated a qualitative research of the economic and social impact of wind farms in Oaxaca. They presented the opinions of the tenants, landowners, developers, municipal authorities, community representatives and opposing groups. Huezca (2011) studied the potencial of the renewable energy technologies for the social development of the communities in Oaxaca, and listed the social conflicts during the construction of large wind farms.

The present research was conducted from August to November of 2013, in a wind farm under construction that contains approximately 6 percent of all wind turbines installed in the Isthmus of Tehuantepec. It was made possible thanks to the help granted by the landowners' representatives with the commitment not to publish the name of the municipality or the name of the wind farm. This measure was requested due to the numerous conflicts that occured in the neighboring towns.

\section{Method}

This research analysed the elements that motivate landowners to rent their properties for the installation of wind farms, and their perception of the impact on the enviroment and the community. In the landowners, only 29 percent have a degree, and 40 percent, only have six years or less of studies.

The research was conducted through a survey with thirteen questions in Likert scale. The options were 1 to 5 , where 1 meant the completely disagreement of the landowner (the landowner perceive some annoyance significantly), and 5 meant total agreement (the impact does not disturb absolutely). The survey also had three questions with different scales to investigate the landowners' plans about agricultural and value property activities, and why they decided to participate in the wind farm project. The questions to measure the perception of the impact on landscape, noise, shadow, crops, property value and distance, were formulated with reference to other research such as Pasqueletti, Gipe \& Righter (2002), Kaldellis (2005), Wolsink (2007), Frolova (2010), Jones (2009), Warren \& McFayed (2010), Katsaprakakis (2012), Nahmad (2011). Opinions of the residents, some landowners, staff of the wind farms developers and construction companies in the Isthmus of Tehuantepec were further developed with questions addressed to know how the landowners perceive the impact on health. 
Their evaluation about renting their properties, the contract clauses, the treatment received from the development company, the municipality image, and their opinions about the agricultural and breeding livestock activities were taken into account.

The questionnaire was reviewed and validated by the landowners' representatives, a development company, and academics in the area of the study. It was distrubuted in one of the meetings the landowners regularly hold, where 63 out of 92 landowners attended. Considering $\mathrm{p}=\mathrm{q}=0.5$, being the first study using this approach in the region, and a confidence level of 95 percent, based on Jauset (2007) the sampling error is 0.48 percent.

The twelve questions in Likert scale were used to know the opinions about the landscape, noise, shadow, crops, breeding livestock activities, human health, distance from town, municipality image, treatment received from the development company, the property value, the balance of their decision to have rented the property and the reading of the contract. The questions were formulated in accordance to the hypothesis that the factors found will be the impact on the enviroment, society and the economy. In addition, two questions were included to analyze any possible change regarding breeding livestock activities and agricultural activities. The last question included six options - not exclusive - aimed to find the reasons that motivated the landowners to participate in the wind project.

This study began with a descriptive analysis to obtain an overview of all the variables that were analized. The software used was trial version Minitab 16.

The information was codified using the software SPPS v. 20. It measured the validity and reliability of the variables through the Cronbach's Alpha and the KMO index. Once the feasibility to use a factorial analysis was confirmed by the interaction matrix and communalities, it was found that the variables distance and reading of the contract could be excluded from the analysis because they did not have a correlation with the other variables. Therefore, their impact on the total variance was small. To better explain the factorial structure, factorial rotation was used with the method of maximun likelihood.

\section{Results}

The study started with an exploratory analysis of the collected information to have an overview of the variables. Figure 1 shows how landowners perceive the variables regarding the impact on the landscape, noise, shadow, crops, breeding livestock activities, health, municipality image, demeanour of the development company, and how the landowners evaluated their decision to participate in the wind project. Most of them rated the impact between indifferent ( 3 in Likert scale) and "agree" (5 in Likert scale). 44 percent of the landowners believed that the property value has doubled as a result of the project. 36 percent believed this increase has been 50 percent. The clauses of contract were evaluated by 53 landowners as regular, by 38 percent as good, and only 7 percent as excellent. 71 percent of landowners affirmed that the contract was read by the development company and 22 percent by any familiar. 

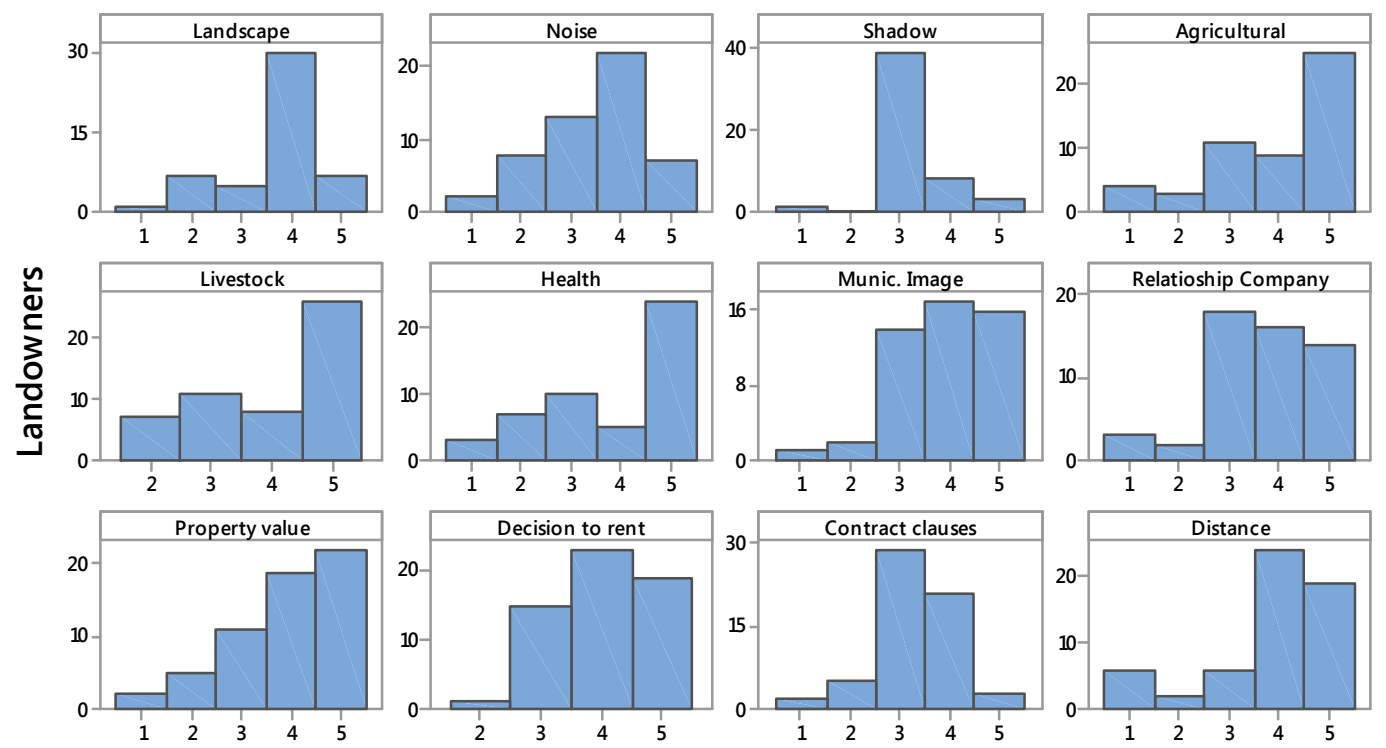

Likert Scale

$1=$ Total disagreement $5=$ Total agreement

Figure 1. Landowner's perception histogram

The figure 1 show some landowners are in total agreement (i.e. they don't perceive any annoyance) with the wind farm ( 4 and 5 of the scale), but is not the total opinion, therefore, the wind farm caused annoyance in other landowners, and this is a very important subject to improve the development process. This is reflected in the opinions about the properties value, where many landowners considered that their properties have increased their value, but not in the same amount, and the quantity of increase is only the landowners's appreciation, these opinions can be different respect of the evaluation of any specialist's opinion. In the contract clauses, though 43 percent of the landowners considered from good to excellent, its very important recognize that the contract was, in the majority of the cases ( 73 percent), read for the company, and other 22 percent by landowners family, its very necessary increase the participation of third parts, especially, lawyers and other experts in the area. Finally, in the landscape, noise, health, agricultural and value property impacts, there are very different appreciations, this results can be result of the lack information in the people, specially remember that the landowners have few years of schooling.

The landowners were asked about their agricultural and breeding livestock activities before renting their properties, and their plans with regard to these activities. The people who were planning to continue these activities every year decreased to seven people, while the number of people who have ocasional activities increased to six. Four are still undecided. This information is shown in Figure 2. 


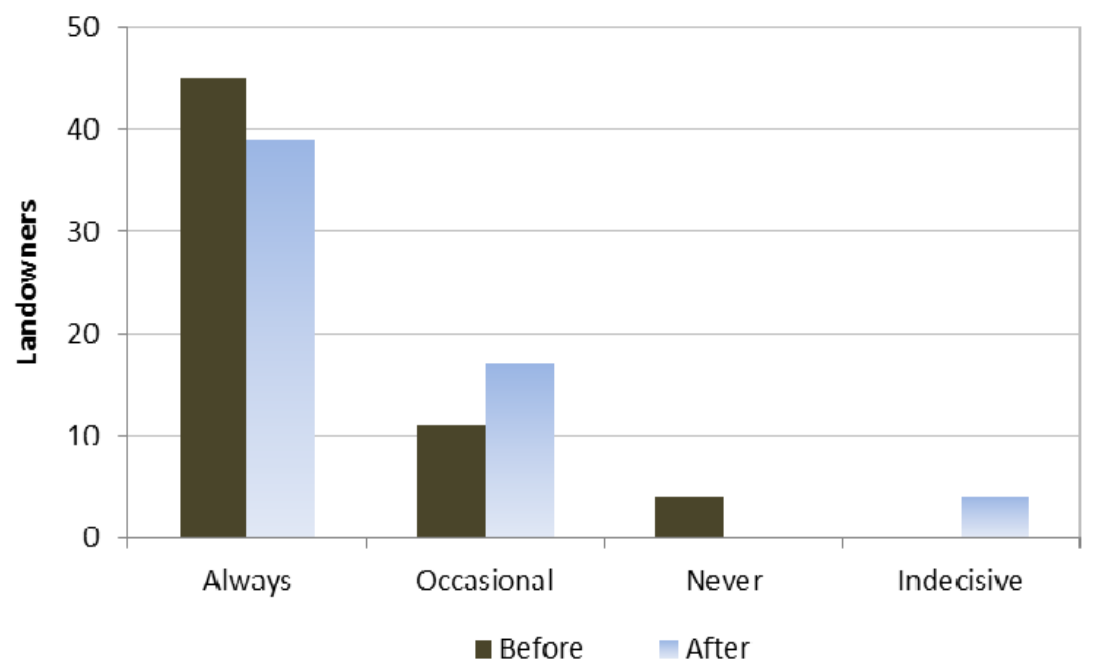

Figure 2. Change in the agricultural and breeding livestock activities

Landowners'attitudes regarding their agricultural and breeding livestock activities were identified. A transition matrix was obtained. Table 1 shows the probabilities which are indicated in parentheses. Of the 45 people that performed these activities every year, nine thought of reducing or eliminating them. Only two people considered increasing these activities from occasional to permanent. The number of landowners doing these activites is reduced to seven, as shown in the figure 3 .

Table 1. Transition matrix in the agricultural and breeding livestock activities

\begin{tabular}{llcccc}
\hline & & \multicolumn{3}{c}{ After } \\
\cline { 3 - 6 } & & Always & Occasional & Indecisive & Never \\
\hline \multirow{2}{*}{$\stackrel{0}{0}$} & Always & $36(0.80)$ & $7(0.15)$ & $2(0.04)$ & $0(0.0)$ \\
& Occasional & $2(0.18)$ & $9(0.82)$ & $0(0.0)$ & $0(0.0)$ \\
& Never & $0(0.0)$ & $1(0.25)$ & $0(0.0)$ & $3(0.75)$ \\
\hline
\end{tabular}

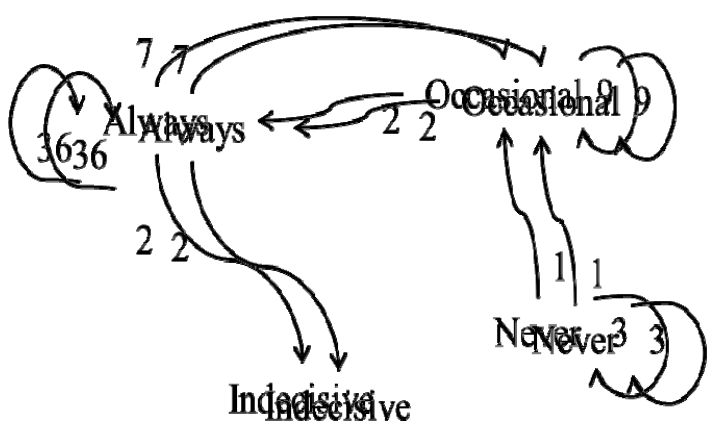

Figure 3. Change in the agricultural and breeding livestock activities

Landowners were asked to indicate the reasons why they accepted and/or supported wind farm development. The options were not exclusive. Figure 4 shows that the main factors are job creation, income from the rent, and the belief that wind farms are a clean energy source. 


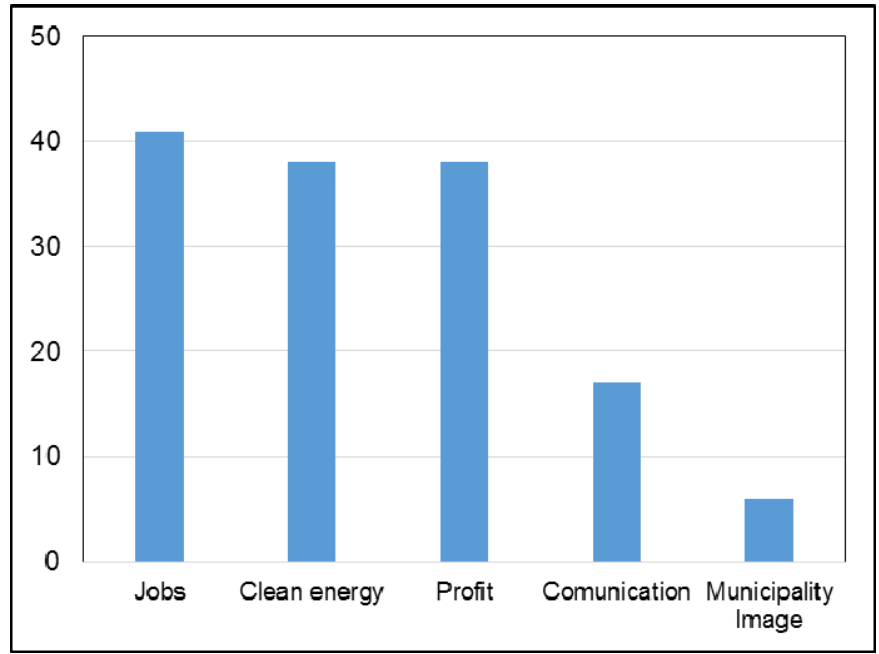

Figure 4. Opinions to support the wind farms

At the end of the descriptive analyzes, the Cronbach's Alpha index of reliability was established at a global scale of 0.872 , in accordance with Oviedo \& Campos (2005), and this value indicates an acceptable internal consistency. The highest value when some items were not taken into account increased to 0.893 , so it was decided to continue with 0.872 .

The factors that the study attempted to analyze were the motivation to rent, and the impact on the environment and society. The correlation matrix was analyzed (Table 2) to validate the information. The matrix shows that distance and reading of the contract do not have significant correlations with the other variables. Considering their communalities it was decided to exclude these variables from the analysis because they explain only a small proportion of the variance.

Before the factorial analysis, a Bartlett's sphericity test was done. The result was highly significant (Chi-square 226 , with a level of significance 0,000 ). Therefore the correlation matrix is not an identity matrix. This shows that there is an association between the answers. The Kaiser-Meyer-Olkin index (KMO, 0.839) confirmed the validity of the data to apply a factorial analysis.

Initially, communalities were analyzed taking all variables into account. However, it was confirmed that distance and the reading of the contract explained little variability. In accordance with the interaction matrix these have minimun interactions with other variables. Therefore, the factorial analysis was done without these variables. Table 3 shows the assigned (initials) communalities and reproduced communalities (extraction) through the factorial solution. Although communalities for noise and shadow were not high, it was decided to keep them in the analysis because they have significant interac-tions with other variables.

Table 2. Communalities

\begin{tabular}{llcc}
\hline & & Initial & Extraction \\
\hline 1. Landscapes & 0.593 & 0.402 \\
2. Noise & 0.390 & 0.134 \\
3. Shadow & 0.505 & 0.312 \\
4. Agricultural & 0.685 & 0.681 \\
5. Breeding livestock activities & 0.686 & 0.663 \\
6. Health & 0.798 & 0.765 \\
7. Municipality image & 0.757 & 0.756 \\
8. Relationship & 0.670 & 0.584 \\
9. Property value & 0.731 & 0.999 \\
10. Decision to rent & 0.748 & 0.714 \\
11. Contract clauses & 0.564 & 0.470 \\
\hline
\end{tabular}

Method of extraction : Maximun likelihood 
With the percentage of variance shown in table 4, the screen plot (figure 5) and the Kaiser's criterion selected two factors with an eigenvalue greater than one. These factors explain almost 68 percent of the total variance.

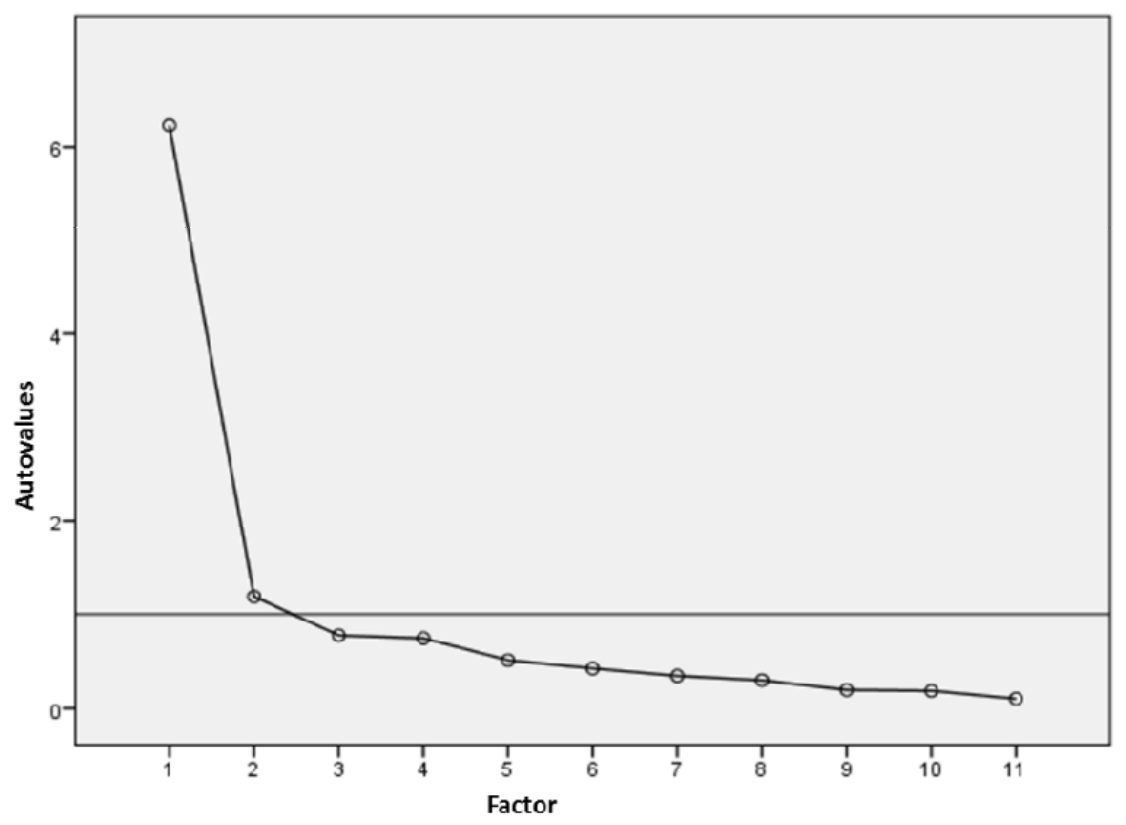

Figure 5. Screen plot (Note 2)

The loading matrix (table 3 ) and the test of goodness-of-fit were obtained. In the test of goodness the Chi-square statistic was 40.002 , with a p-value of 0.221 . Both were evidence that the method of extraction was correct. The factors structure can be identified in the matrix of components (table 3). Factor 1 corresponds to the motivation to participate in the wind farm project. Factor 2 is about the impact on the habitat.

Table 3. Components matrix

\begin{tabular}{llcc}
\hline & & \multicolumn{2}{c}{ Factor } \\
\cline { 3 - 4 } & & 1 & 2 \\
\hline 1. & Property value & $\mathbf{0 . 9 9 9}$ & -0.008 \\
2. & Decision to rent & $\mathbf{0 . 7 5 4}$ & 0.380 \\
3. & Relashionship & 0.684 & 0.340 \\
4. & Health & 0.637 & $\mathbf{0 . 5 9 9}$ \\
5. Landscape & 0.517 & 0.367 \\
6. & Contract clauses & 0.494 & 0.475 \\
7. Beeding livestock activities & 0.448 & $\mathbf{0 . 6 8 0}$ \\
8. Municipality image & 0.587 & $\mathbf{0 . 6 4 1}$ \\
9. Agriculture & 0.556 & $\mathbf{0 . 6 1 0}$ \\
10. Shadow & 0.261 & $\mathbf{0 . 4 9 4}$ \\
11. Noise & 0.256 & 0.262 \\
\hline
\end{tabular}

Method of extraction: Maximum Likelihood

From the residuals obtained, the goodness of the model is deemed adquate. The residuals are small. However, 27 percent of them are absolute values greater than 0.05 . Thus the factor rotations was performed to improve the interpretation of the loads, Table 4.

The rotation shows that factor 1 is related to the impact on the image of the town, beeding livestock acvities, health and whether wind farms are appropriate in the town. The matrix interaction of the factorial analysis shows that variables such as shadow, landscape and noise had significant interaction with town image. This is possibly because these variables are implicit within this image. Factor 2 consists of the variables that influence the 
decision of participating in the project. The contract clauses are possibly implicit within the treatment given by the companies. It is very important recheck again, althought reading of the contract was not significant in the factorial analysis, its necessary analyse it in the future with cualitative approachment, because the landowners is a group of few schooling, and the contract was reading for the developer company, mainly, and non-specialists.

Table 4 . The rotated factors matrix

\begin{tabular}{llcc}
\hline & & \multicolumn{2}{c}{ Factor } \\
\cline { 2 - 3 } 1. Beeding livestock activities & $\mathbf{0 . 7 6 8}$ & 2 \\
2. Municipality image & $\mathbf{0 . 7 6 4}$ & 0.272 \\
3. Health & $\mathbf{0 . 7 3 4}$ & 0.416 \\
4. Agriculture & $\mathbf{0 . 7 2 6}$ & 0.475 \\
5. Contract clauses & 0.580 & 0.393 \\
6. Shadow & 0.542 & 0.366 \\
7. Landscape & 0.481 & 0.135 \\
8. Noise & 0.316 & 0.414 \\
9. Property value & 0.233 & 0.186 \\
10. Decision to rent & 0.551 & $\mathbf{0 . 9 7 2}$ \\
11. Relashionship & 0.495 & $\mathbf{0 . 6 4 1}$ \\
\hline
\end{tabular}

\section{Discussion}

In accordance with the descriptive analysis, the landowners apparently are agree with the development of the wind project, however, in the landscape, noise, health, agricultural and value property impacts, have much variability in the appreaciations. Therefore, some landowners agreed to participate in the project, but they don't have certain about the impacts of the wind farm.

The landowners support installation of wind farms because it creates new jobs, income such as rent and other services, and because they consider the wind farms a clean source of energy. Regarding income, nine landowners who engage in agricultural or value property activities, every year are considering decreasing these activities, and three landowners are thinking of increasing them.

The results of this study show that in the mayority of cases landowners perceive as positive the impact on agriculture, beeding livestock activities, town image, and health. Landowners believed there is a rise in their property value, and they regarded the relationship with the development company as positive.

A potential third factor, with regard to the clauses of the contract, shadow, landscape and noise, was not empirically supported. Nevertheless, these variables interact with other variables, and any change in these could affect the structure of the factors found. But, due the importance of clauses and contract reading, and the conditions of age and schooling of the landowners, it is necessary apply a new study with qualitative approach to analyse them, because, the contract reading was realized for the developer company and non-specialists.

It is necessary to replicate it in other towns in the area and in other sectors to ascertain social perceptions. As this study was done in one wind farm under construction, now there is an opportunity to replicate it later to compare the perception of themselves landowners. Oaxaca is a very complex state and has around $25 \%$ of counties in all Mexico (570 of 2378 in total) this is due to sense of singularity that diferentes communities has Oaxaca.

Even the general perception of benefits is high in Oaxaca case in comparation with other nations, and aspects like noise, and landscape distortion are not as important for local owners, the more important aspect were: Value property, Municipality image, Health and Agriculture. Finally, because land owners basic education we recommend that they must be advised by specialists in local university in the aggrement arregenments.

\section{References}

Alemán-Nava, G. S., Casiano-Flores, V. H., Cárdenas-Chávez, D. L., Díaz-Chávez, R., Scarlat, N., Mahlknecht, J., Dallemand, J. F., \& Parra, R. (2014), Renewable energy research progress in Mexico: A review. Renewable and Sustainable Energy Reviews, 32, 140-153. http://dx.doi.org/10.1016/j.rser.2014.01.004

Association of Renewable Energy Producers. (1999). Environmental impacts of electricity production. Spain: Ministry of Science and Technology. Retrieved July 15, 2013, from http://www.appa.es/descargas/Resumen_Estudio_ACV.pdf 
Barbará-Gómez, L. (2009). El mercado de la energía eólica en México. Monterrey: ICEX.

Bárcenas, L. (2012 ). Wind companies and rights of peoples in the Isthmus of Tehuantepec. La Jornada. Retrieved September 10, 2013, from http://www.jornada.unam.mx/2012/12/15/opinion/018a1pol

Baxter, J., Morzaria, R., \& Hirsh, R. (2013). A case-control study of support/opposition to wind turbines: Perceptions of health risk, economic benefits, and community conflict. Energy Policy, (61), 931-943. http://dx.doi.org/10.1016/j.enpol.2013.06.050

Beas, C. (2012). Three Myths of wind megaproject of the Isthmus of Tehuantepec. La Jornada. Retrieved September 3, 2013, from http://www.jornada.unam.mx/2012/11/03/estados/023alest

Carro, D. (2008). A social perspective of wind energy: Reflections and recommendations about the social impact and acceptance of parks. National Congress of the Environment. Madrid, Spain. Retrieved August 21, 2013, from http://www.conama9.conama.org/conama9/download/files/CTs/2493_DCarro.pdf

Castillo, E. (2011). Problems surrounding the construction of wind farms in the Isthmus of Tehuantepec. Retrieved August 22, 2013, from http://www.eumed.net/rev/delos/12/ECJ-Parques\%20eolicos.pdf

Dai, K., Bergot, A., Liang, C., Xiang, W. N., \& Huang, Z. (2015). Enviromental issues associated with wind energy - A review. Renewable Energy, 75, 911-921. http://dx.doi.org/10.1016/j.renene.2014.10.074

del Campo, C. M., Nelson, P. F., \& García, M. A. (2009). Wind energy in Mexico: Simulation of a wind farm and application of probabilistic safety assessment. Engineering, Research, 10(4), 343-352.

Déniz, J. J., de la Rosa, M. E., \& Verona, M. (3-5 de Octubre de 2012). The social impact of Spanish wind energy companies in the rural communities of Oaxaca and its reflection on sustainability. In: $X V I I$ International Congress in Accounting, Administration and Information Technology. D.F., Mexico: UNAM.

Devine-Wright, P. (2007). Reconsidering public attitudes and public acceptance of renewable energy technologies: a critical review. (U. o. School of Environment and Development, Ed.) Recuperado el 15 de 02 de 2015, de http://geography.exeter.ac.uk/beyond_nimbyism/deliverables/bn_wp1_4.pdf

Enel Green Power. (2012). ENEL second wind farm opens its network in Mexico. Retrieved November, 12, 2013, from http://www.enelgreenpower.com/en-GB/plants/projects/mexico/bii_nee_1ll/

Energy News. (2012). Mexico - Bii Nee Stipa III. Retrieved November 16, 2013, from http://www.energynews.es/enel-inaugura-el-segundo-parque-e-lico-de-su-red-en-m-xico-1355814939/

Evans, A., Strezov, V., \& Evans, T. J. (2009). Assessment of sustainability ondicators for renewable energy technologies. Renewable ans Sustainable Energy Reviews, 13, 1082-1088.

Fast, S. (2013). Social Acceptance of Renewable Energy: Trends, Concepts, and Geographies. Geography Compass, 7(12), 853-866. http://dx.doi.org/10.1111/gec3.12086

Frolova, M. (2010). The landscapes of wind energy: its social perception and management in Spain. Nimbus: Journal of Climatology, Meteorology and landscape, (25-26), 93-110.

García, C. (2011). First Forum of renewable energy and climate change - Oaxaca. Retrieved October 25, 2013, from http://www.ciedd.oaxaca.gob.mx/foro/info/pdf/b3carlos_garcia_aguilar.pdf

Global Wind Energy Council. (2012). Global Wind Report Annual Market Update 2012. Retrieved October 22, 2013, from http://www.gwec.net/wp-content/uploads/2012/06/Annual_report_2012_LowRes.pdf

Global Wind Energy Council. (2014). Global Wind Statistics 2013. Retrieved February 10, 2014, from http://www.gwec.net/wp-content/uploads/2014/02/GWEC-PRstats-2013_EN.pdf

Grupo Bimbo. (2013). Wind Farm Piedra Larga. Retrieved January 15, 2014, from http://www.grupobimbo.com/es/grupo-bimbo-verde/infografia-verde-3/parque-eolico-piedra-larga.html

Hammarlund, K., \& Martensson, A. L. (1999). Planning for acceptance Windpower in a social landscape. 1999 European Wind Wnergy Conference (págs. 582-585). Nice: James \& James .

Han, J., Mol, A. P., Lu, Y., \& Zhang, L. (2009). Onshore windpower development inChina: Challenges Behind a successful story. Energy Policy, 37, 2941-2951. http://dx.doi.org/10.1016/j.enpol.2009.03.021

Huacuz, J. M. (2010). Wind energy, How to tap its value? Science and development, 36(240), 34-40.

Huezca, P. M. (2011). Wind Energy potential for social development in Oaxaca. master's thesis. National Autonomous University of Mexico, México.

Improta, R. (2011). Impact psycho-socio-environmental process of building a wind farm: a novel area of 
research in psychology. III International Conference on Research and Professional Practice in Psychology XVIII Seventh Conference on Research Meeting of Researchers in Psychology MERCOSUR. Buenos Aires, Argentina: School of Psychology - University of Buenos Aires.

Jauset, J. A. (2007). Statistics for journalists and media advertising. Barcelona.: Editorial UOC.

Jobert, A., Laborge, P., \& Mimler, S. (2007). Local acceptance of wind energy: Factors of success identified in French and German case studies. Energy Policy, (35), 2751-2760. http://dx.doi.org/10.1016/j.enpol.2006.12.005

Jones, C. R. (2009). Identyfing predictors af attitudes towards local onshore wind development with reference to an English case study. Energy Policy, 37(11), 4604-4614. http://dx.doi.org/10.1016/j.enpol.2009.06.015

Kaldellis, J. K. (2005). Social attitude towards wind energy applications in Greece. Energy Policy, 33(5), 595-602. http://dx.doi.org/10.1016/j.enpol.2003.09.003

Kaldellis, J. K., Kapsali, M., \& Katsanou, E. (2012). Renewable energy applications in Greece - What is the public attitude? Energy Policy, 42, 37-48. http://dx.doi.org/10.1016/j.enpol.2011.11.017

Katsaprakakis, D. A. (2012). A review of the environmental and human impacts from wind parks. A case study for the Prefecture of Lasithi, Crete. Renewable and Sustainable. En: Energy Reviews, 16(5), 2850-2863. http://dx.doi.org/10.1016/j.rser.2012.02.041

León-González, C., Araña-Padilla, J., González-Hernández, M., \& Suárez-Reina, B. (04 de 10 de 2013. Report on the environmental impact $<$ Canary marine exploration Polls $>$. Canaria: University Las Palma of Gran Canaria.

Matías, P. (2012). Order judge to suspend wind project in the Isthmus of Tehuantepec. Retrieved October 25, 2013, from http://www.proceso.com.mx/?p=327301

Misrasgedis, S., Tourkolias, C., Tzovla, E., \& Diakoulaki, D. (2014). Valuing the visual impact of wind farms: An application in South Evia, Greece. Renewable and Sustainable Energy Reviews, (39), 296-311. http://dx.doi.org/10.1016/j.rser.2014.07.100

Nahmad, S. (2011). The social impact of the use of the wind resource. Oaxacan Council for Science and Technology. Mexico.

Oviedo, H. D., \& Campos, A. (2005). Approach to the use of Cronbach's alpha. En: Colombian Journal of Psychiatry, 34(4), 572-580.

Pasqualetti, M. J. (2011). Opposing Wind Energy Landscapes: A Search for Common Cause. Annals of the Association of American Geographers, 101(4), 907-917. http://dx.doi.org/10.1080/00045608.2011.568879

Pasqueletti, M. J., Gipe, P., \& Righter, R. W. (2002). Wind power in view: energy landscapes in a crowed world. San Diego: Academic Press.

Pedersen, E., \& Persson, W. K. (2004). Perception and annoyance due to wind turbine noise- a dose-response relationship. The Journal of the Acoustical Society of America, 116, 3460-3470. http://dx.doi.org/10.1121/1.1815091

Rygg, B. J. (2012). Wind power-An assault on local landscapes or an oppotunity for modernization. Energy Policy, 48, 167-175. http://dx.doi.org/10.1016/j.enpol.2012.05.004

SE. (2013). Renewables Energy. Retrieved November 22, 2013, from http://mim.promexico.gob.mx/work/sites/mim/resources/LocalContent/42/2/130726_DS_Energias_Renova bles_ES.pdf

Soini, K., Pouta, E., Salmiovirta, M., Uusitalo, M., \& Kivinen, T. (2011). Local residents' perceptions of energy landscape: the case of transmission lines. Land Use Policy, (28), 294-305. http://dx.doi.org/10.1016/j.landusepol.2010.06.009

The Wind Power. (2014). Wind farms in Mexico. Retrieved August 12, 2013, from http://www.thewindpower.net/country_windfarms_es_36_mexico.php

Thomas, G. (25 de 08 de 2013). In collective fight burn wind farm machinery Juchitán. Retrieved August 25, 2013, from http://www.radioformula.com.mx/notas.asp?Idn=349749

Trobo, M. (2013). Wind power and social acceptance: Lessons for Uruguay and guide to action. Uruguay: Ministry of Industry, Energy and Mining. 
van den Berg, G. P. (2004). Effects of the wind profile at night on wind turbine sound. Journal of Sound and Vibration, (277), 955-970. http://dx.doi.org/10.1016/j.jsv.2003.09.050

Walter, G. (2014). Determining the local acceptance of wind energy projects in Switzerland: The importance of general attitudes and project characteristics. Energy Research \& Social Science, (4), 78-88.

Warren, C. R., \& McFayed, M. (2010). Does community ownership affect public attitudes to wind energy? A case study from south-west Scotland. En: Land Use Policy, 27(2), 204-213. http://dx.doi.org/10.1016/j.landusepol.2008.12.010

Wolsink, M. (2007). Wind power implementation: The nature of public attitudes: Equity and fairness instead of backyard attitudes. En: Renewable and Sustainable Energy Reviews, 11(6), 1188-1207. http://dx.doi.org/10.1016/j.rser.2005.10.005

Wolsink, M. (2013). Wind Power : Basic Challenge Concerning Social Acceptance. In R. A. Meyers (Ed.), Encyclopedia of Sustainability Science and Technology, 17, 12218-12254. Springer New York.

\section{Notes}

Note 1. The terajoule (TJ) is equal to one trillion (1012) joules. About $63 \mathrm{TJ}$ of energy was released by the atomic bomb that exploded over Hiroshima. The joule (/'dzu:1/ or sometimes /'dzavl/), symbol J, is a derived unit of energy in the International System of Units.[1] It is equal to the energy transferred (or work done) when applying a force of one newton through a distance of one metre (1 newton metre or $\mathrm{N} \cdot \mathrm{m}$ ), or in passing an electric current of one ampere through a resistance of one ohm for one second. It is named after the English physicist James Prescott Joule (1818-1889).

Note 2. The scree plot is used to determine the optimal number of factors. Simply is a graphical representation of the size of the eigenvalues in this case is 11 .

\section{Copyrights}

Copyright for this article is retained by the author(s), with first publication rights granted to the journal.

This is an open-access article distributed under the terms and conditions of the Creative Commons Attribution license (http://creativecommons.org/licenses/by/3.0/). 